\title{
DIVINE LEGITIMATION OF JUDICIAL POWER AND ITS ICONOGRAPHICAL IMPACT IN WESTERN CULTURE
}

\author{
Georges Martyn ${ }^{1}$
}

\section{Abstract}

From a historical and anthropological point of view, there is a close link between religion and the judicial function, in many cultures throughout the world. How could man be competent to judge his equals if he was not empowered to do so by God? In many cultures, originally, the same 'functionaries' administer both religious and judicial affairs. In medieval Europe, Christian faith and the Roman Catholic Church play a role of paramount importance in the heart of society, not only for the mere religious services, but also in politics and culture. The influence of the Church on justice administration (both via its own courts and via its interference in secular courts) is enormous. Religious texts are used as legal arguments, ${ }^{2}$ but also to legitimate the judicial function and its decision makers. And not only texts! Also (religious) images are vehicles of legitimation. The Last Judgment, in the first place, is omnipresent, in manuscripts and printed books, but also as a classical decoration for justice halls. This article looks at a number of concrete examples from art history, and tries to describe and analyse how both the divine word and image were used to legitimize the emerging 'modern' courts of Princes and cities. These courts, using the Romano-canonical procedure, are the forerunners of the present day judiciary. Today's court setting, the use of red robes and green curtains, or the ritual of the oath, are just some remaining, observable aspects of an age-old charismatic, because divine, legitimation, using images as vectors of meaning.

Keywords

Legal Iconology. Legal Iconography. Legitimation. Judicial Function. Christian Iconography. Tree. Oath.

\section{Summary}

1. Early testimonies of 'justice places'. 2. The emergence of the 'modern' court in the late Middle Ages. 3. Late medieval spatial organization of justice. 4. The Last Judgment. 5. Legitimation and example. 6. Conclusion: a double but slow emancipation.

1 Full professor of legal history. Faculty of Law and Criminology. Ghent University Flanders (Belgium).

The author thanks dr. Stefan Huygebaert (Faculty of Arts. Ghent University) for his enriching suggestions.

${ }^{2}$ RenOuX-ZAgame 2015, 386. 


\section{EARLY TESTIMONIES OF 'JUSTICE PLACES'}

The Constitutional Court of South Africa's logo is a round symbol of black and white people coming together under a tree with eleven branches (referring to the State's eleven official languages). ${ }^{3}$ The 'holy' tree is, throughout history, also in many other regions a symbol of justice, and its immediate surroundings are more concretely the place where justice is administered. Judges gather under a tree. ${ }^{4}$ In many European countries, still today, place names refer to the location of the former justice tree. Often, a historical species, or its substitute, is still present. ${ }^{5}$

Anthropologically, it comes to no surprise that individuals and groups attribute special features to a big, strong and impressive tree in the centre of the community, or at least in the neighbourhood of their habitat (sometimes on a holy hill or near a mystic water spring). Before the introduction of monotheistic religions, when divinity is supposed to house in the sun and the moon, or in thunder and lightning, trees radiate special powers. While men and women die, just like animals and smaller plants, trees only seem to fall asleep every autumn and winter, to revive in spring, and grow taller and taller, every year again. Generations come and go, but

${ }^{3}$ https://www.concourt.org.za/. The court's building, moreover, has several architectural and artistic features linking justice and art (including other references to the justice tree), and holds a remarkable art collection, see https://www.ccac.org.za/ and https://www.constitutionhill.org.za/pages/constitutional-court-art-collection. A beautiful illustrated book is Ben Law-Viljoen (ed.), Art and Justice: The Art of the Constitutional Court of South Africa, Johannesburg, 2008.

${ }^{4}$ Although particularly concentrating on France, a good overview of the justice's spatial history is JACOB and MARCHAL-JACOB 1992. A more recent great overview of the history of courts, from ancient times to today's United States is RESNIK and CURTIS 2011, especially the chapter 'From 17th century Town Halls to 20th century courts', 134-153. In pagan Europe already, Celts, Scandinavians and Germanic people sat under a tree to decide, NeTTEL 2005, 529-530. See also Mulcahy 2011.

${ }^{5}$ For Germany, see LENZING 2005, NeTTEL 2005, 529; WeBER 1997, 149; for the Low Countries VISSER and MOENS 2006. 
the age-old tree survives them all. The same trunk that witnessed gatherings, disputes and decisions of ancestors, continues to inspire the younger. Storms and floods destroy crops and houses, while the holy tree still stands after all disasters. In Europe, especially oaks and lime trees seem to be the most popular types to play this role. ${ }^{6}$

Under the village's tree, is where justice is administered, because justice administration is one of the higher tasks within community life, just like religion is. Justice has in some sense a sacred aura, and therefor needs rituals. ${ }^{7}$ Within these rituals, the need for a sacred justice place is of paramount importance. Hence, delimiting the justice space is a crucial first step in the process of bringing parties together, gathering the decision makers or mediators, and coming to a decision. ${ }^{8}$

It is not this contribution's objective to investigate whether the link between justice administration and religion, geographically coming together in the 'sacred place of justice' (not to be mixed up with the place of execution) is a mere anthropological fact, or a cultural historical construct. ${ }^{9}$ Nor is it possible to describe the various concrete steps in the long history of the Christianisation of the European countries, today belonging to what can be called 'Western legal culture'. A lot has been written on how more 'pagan' the 'Christian Middle Ages' might have been than traditionally thought and taught; as well as on how pre-historic symbols and rituals were Christianised, adapting old customs to new beliefs. ${ }^{10}$ The present article's objective is to describe, referring to some concrete works of art, how, also

${ }^{6}$ VisSer and MOENS 2006. JACOB 1994, 39-64, beautifully links the age-old tree to the 'pillar of the world', linking heaven and earth, in later centuries often substituted by a stone column as symbol of justice and power, as well as by the Holy Cross; MULCAHY 2011, 1517.

7 Arlinghaus 2004; GARAPON 1997, especially 23 and 38-39; OeSTMANN 2006; OSTWALDT 2006.

${ }^{8}$ SCHMIDT 2006.

${ }^{9}$ GARAPON 1997, 24, explicitly warns not to see it as a mere anthropological given.

${ }^{10}$ E.g. LE GOFF 1988; VAN ENGEN 1986 and 1991. 
in de Late Middle Ages and Early Modern and Modern Eras, religious - in Weberian terms 'charismatic' - symbols became symbols of justice, and how the judiciary used, and often still uses, (religiously inspired) images to legitimate its power.

As far as justice administration is concerned, in the fourth century, the actual procedural rules of justice administration and its practical organisation do not change in the heart of the Roman Empire, when the Christian faith is first tolerated under Constantine, and finally established as the official State religion under Theodosius. However, just like formerly Roman gods and sacred rituals accompanied justice, in an imperial constitution Justinian explicitly orders to bring the Holy Bible to the forum, and hear the parties and decide the cases 'in the presence of God'. ${ }^{11}$ This sixth century rule, bringing the Holy Scriptures to the place of justice, can be seen a ritual forerunner of the presence of the Last Judgment in medieval courtrooms (infra), as 'being consecrated by the presence of God, [the judges] dispose

${ }^{11}$ In the title of the Justinian Code on judgments (III.1), a 530 constitution rules (English text by S.P. Scott, Cincinatti, 1932): 'We are not introducing anything that is new or unusual, but only what has already been established by the ancient legislators, for ever since these rules have been treated with contempt, no small injury to litigation has resulted. For who is ignorant of the fact that judges in former times could not accept the judicial office unless they had previously made oath that they would on all occasions decide according to the truth, and in compliance with the law? Therefore, as We have found that [...] generally speaking, all judges learned in the Roman Law, shall not undertake to hear a case, unless the Holy Scriptures have previously been placed in front of the judicial tribunal, and remain there, not only during the beginning, but also throughout the entire examination, until the very end, and the promulgation of the final decision. If, therefore, paying attention to the Holy Scriptures, and being consecrated by the presence of God, they dispose of litigation with the aid of a higher power, let them know that they must not judge others in any other way than they themselves are being judged, as this will be more terrible to them than to the parties themselves; for while the litigants are judged by men, they themselves introduce cases to be weighed and determined with the assistance of God. This judicial oath shall be made known to all, and shall be added by Us to the Roman Law, and be observed by all magistrates $[\ldots]$ '. 
of litigation with the aid of a higher power, let them know that they must not judge others in any other way than they themselves are being judged, as this will be more terrible to them than to the parties themselves; for while the litigants are judged by men, they themselves introduce cases to be weighed and determined with the assistance of God'.

Pagan ethnical groups make the Western empire collapse already in the fourth and fifth century, while it takes almost a millennium to end the Byzantine Empire. In the Early Middle Ages, in Europe, with strong divergences from North to South and East to West, Christianism firstly retrocedes, but then re-establishes, not only as a religion, but also as an institution. As organised structure, the Church, with its main seat in Rome, manages to survive the fall of the Western Roman Empire. For knowledge in general, but particularly for what law and legal science is concerned, one cannot overestimate the bridging role the Church plays between Antiquity and the Middle Ages. Via cathedral schools and monasteries, later via universities, the Church is the custodian of 'books'. 'The book', of course, is the main source of wisdom. But, as 'ecclesia lege romana vivit', one should particularly stress the safeguarding of the Roman legal heritage. The Church uses and slowly adapts Roman terminology, concepts, rules and structures. And it is also a transmitter of a lot of legal-iconographical symbolism. ${ }^{12}$

When ethnic group by ethnic group, or territory by territory, is Christianised, this not only opens the path to (re-)Romanisation of the law by various channels of legal transplantation - seen in a rather dogmatic topdown vision -, but it also paves the way for a Christianisation of the judicial ritual - looking at the daily justice administration by the local and customary benches and dispute settlement organs from a more sociological bottom-up perspective. The pagan justice tree in particular is fluently adapted to the new socio-religious context, both practically and theoretically.

Very practically spoken, 'holy' trees are allowed to continue their sacred function. A crucifix, often made by the tree's own branches, is fixed to the

12 Carlen 2004. 
trunk. Or it is the place where a statue of the Virgin Mary is hosted. In Germanic regions, Mary is substituting the goddess Freya. ${ }^{13}$ In some tree crowns the apparition of Christ's Mother is witnessed, while many trees (with symbols attached to them or chapels underneath) become the centre of pilgrimages and worshipping.

The distribution of the Holy Word also theoretically substantiates the relation between justice and God, religion, the priests, and particularly the tree's vocation as the sacred place for justice administration. ${ }^{14}$ In Deuteronomy $17,8-9,{ }^{15}$ it is stated: '(8) If there arise a matter too hard for thee in judgment, between blood and blood, between plea and plea, and between stroke and stroke, being matters of controversy within thy gates: then shalt thou arise, and get thee up into the place which the Lord thy God shall choose; (9) And thou shalt come unto the priests the Levites, and unto the judge that shall be in those days, and enquire; and they shall shew thee the sentence of judgment'. Particularly the Ancient Testament book Psalm was influential in offering legitimising texts, as in this book the earthly King, the priest and the judge are described as God's representative, invested with jurisdictional power. ${ }^{16}$ Justice, like power in general, ${ }^{17}$ is delegated to man, but it is administered in the name of God. According to 2 Chronicles 19:6: 'And said to the judges, Take heed what ye do: for ye judge not for man, but for the Lord, who is with you in the judgment.' And where does man sit in judgment? A justice tree is explicitly mentioned in the Bible. In Judges 4:4-5, a female judge is mentioned, sitting under a palm. ${ }^{18}$

13 VISSER and MOENS 2006.

14 CHASSAN 1847, passim.

15 For all Bible quotes is made use of the King James version, available, a.o., at www.biblegateway.com.

16 SCHILD 1995, 121-125 gives several other biblical references.

17 DEUTSCH 2012.

18 '(4) And Deborah, a prophetess, the wife of Lapidoth, she judged Israel at that time. (5) And she dwelt under the palm tree of Deborah between Ramah and Bethel in mount Ephraim: and the children of Israel came up to her for judgment.' 


\section{THE EMERGENCE OF THE 'MODERN' COURT IN THE LATE MIDDLE AGES}

When, in the First Middle Ages, the many ethnic groups travelling and settling across Europe are Christianized, this does not immediately bring along new institutions and rituals for justice administration. However, within the dispute settlement processes, divine legitimation shifts from pagan to Christian belief. Illustrative, for instance, is the survival of irrational methods of proof, taking up, however, Christian elements. The ordeal by boiling water or by hot iron probably has pagan roots, but the fact that the suspect has to come back to court and show his wounds after three days, is a clear reference to Trinity and the three days from the dead of Christ to his resurrection at Easter. ${ }^{19}$ Pagan methods like the use of oracle branches lose popularity, while clearly Christian inspired irrational proofs are installed, like the iudicium crucis: the two parties claiming opposing views have to raise their arms and stand in the form of a cross. The one lowering his arms first, loses the process, as the stronger one is thought to have God's help. $^{20}$

While the Fourth Lateran Council in 1215 forbids these kinds of ordeals, ${ }^{21}$ it has to be underlined that probably the most 'irrational' proof, on the contrary, starts to play a crucial role: the individual oath, a concept with theological and canonical roots. The strength of the oath is namely exactly the fact that it is based on the relation between one's individual soul and divine justice. Breaking an oath or not telling the truth while under oath

19 The person undergoing this ordeal had to pick up a glowing metal or had to stick his hand in a fire or in a pot of boiling water. The wounds were bandaged and re-revealed after three days. Well curing wounds meant that the person was 'clean', i.e. unguilty, while inflammation of the wounds stood for guilt.

${ }^{20}$ GANSHOF 1963; BARTLETT 1986.

21 SuTTER 2008, 97-99; VAN CAENEGEM 1990, 264 and 274. 
might lead to eternal damnation. And this makes it, in the Christianized Middle Ages, a very strong weapon in the search for the judicial truth.

When taking the oath, in most cases, ${ }^{22}$ one has to put one hand on the Bible, on a crucifix or on relics, ${ }^{23}$ while raising the other hand, and more particularly thumb, index and middle finger, to heaven. ${ }^{24}$ The three fingers, again, refer to the Holy Trinity, and are both used for the blessing gesture as for the oath. The gesture is represented in some very meaningful latemedieval justice paintings. Remarkable is the panel Taking the oath by Derick Baegert (1440-1515). ${ }^{25}$ At the front, in the middle, we can see a court functionary holding up some kind of relic shrine, topped by a cross, in front of a man who is to take an oath. He has already risen his right hand, showing three fingers. At the back, seated on an elevated bench, sit the judges. The court's president explicitly points at the painting of the Last Judgment hanging in the courtroom (it is a 'picture in the picture'). Baegert's painting witnesses the presence of the representation of the Last Judgment in courtrooms (infra), but it also most explicitly shows how late-medieval citizens were 'iconographically convinced' of the vital importance of the oath. ${ }^{26}$ To the left and to the right of the central oath taker appear, namely,

22 Just like there are different kinds of oaths, there are also many other (however, less common) rituals for swearing the oath, DILCHER 1971; SCHRAGE 2005, 32.

${ }^{23}$ For examples of the use of a crucifix when taking an oath, see DE BUSSCHER 1866, 71 (Ghent, the oath crucifix used in both of the city's aldermen benches); MOELANDS 2003, 172 and 176 (Bruges, the oath of a tutor).

${ }^{24}$ CALLEWAERT 2009; DiLCHER 1971. For the iconographical representation of the oath, see GOMBRICH 1986.

25 Wesel (Germany), Städtisches Museum-Galerie im Zentrum, 1493-1494, oil on panel, $149,5 \times 173,5 \mathrm{~cm}$. Images of the paintings mentioned in this article can easily be found on the worldwide web by entering title and artist's name. A woman taking the oath, raising three fingers, is pictured in a very analogous painting commissioned by Graz's city judge Nicolas Strobel, representing both the earthly judge as a Last Judgment above, see KOCHER 1992, 103, ill. 152.

${ }^{26}$ On the idea of 'learning by seeing', or 'quod legentibus scriptura, boc idiotas pictura', see ILLMAN MEYERS 1996. FRANCA 2018, 160, beautifully calls it the muta eloquentia. 
a devil and an angel. The first one challenges the man to lie, stating (translating the words written in golden letters on the panel): 'Hold up your hand, do not be ashamed, you can swear in all devils' name!' The angel, however, whispering in the man's ear, warns: 'Do not take a false oath, or you will lose your eternal well'. It is a clear reference to the Last Day, when all souls will be judged by God himself.

The Baegert painting clearly illustrates that by the fifteenth century (it is hard to find older panel paintings, but also in illustrated manuscripts representations of courtrooms are very scarce ${ }^{27}$ ) canon law and religion thoroughly influence justice administration. The learned law, studied and taught by legists and canonists at the universities, had penetrated law and justice piecemeal, particularly from the late eleventh century onwards. One of the main constructions of this ius commune's late-medieval intellectual and practical cooperation is the Romano-canonical procedure. ${ }^{28}$ Similar rules for both civil and criminal trials spread all over Europe via various 'channels of reception': the establishment of new universities, de divulgation of manuscripts and printed books (often handbooks for local use), the professionalization of law and justice, new legislation by emerging absolute rulers, the codification of customary law etc. Making appeal possible and the establishment of central courts enhances the reception of the new procedural rules and concepts, based on both Roman and canon law. Whereas in the old customary local benches, old wise men applied unwritten rules, in the new courts learned men apply written texts.

At this point, images have a role to play. While the reception makes that the legal language is no longer the local customary one, but starts to become a specialists' jargon, images can 'talk' to all. 'Language divides, but vision unites', as Goodrich writes. ${ }^{29}$ Moreover, the shift to a mere rationally built

\section{${ }^{27}$ L'ENGLE 2001.}

28 SCHMOECKEL 2008; VAN CAENEGEM 1973.

${ }^{29}$ GOODRICH 2013, 508: 'The visual is the primary means and medium for transmitting law because, like law, it touches all [...]'. 
legal and judicial system, may probably enhance the need for extra charismatic legitimation. And in this context, iconography has its merits. The use of images is crucial for the grandeur and gravitas of law and justice. ${ }^{30}$ A great example of the fundamental role of Roman and canon law for latemedieval justice administration, is the iconographical project (1508-1511) by Rafael (1483-1520) for the Vatican Stanqa della segnatura, a hall used as a courtroom for the papal Signatura Gratiae audiences. On the ceiling, literally exalted as highest virtue, is Lady Justice, with downcast eyes, sword and scales. The entrance to the room, however, is flanked by two paintings, composing, together with the three other cardinal virtues above the door, what has been called 'the justice wall' (as the other walls are illustrating the other three of the four humanist aspects of culture and wisdom: theology, philosophy, poetry and justice). Fundamental legal texts are represented here, as the Emperor Justinian is receiving the Digest from Tribonian, and Raymond of Peñaforte is offering his Liber Extra to pope Gregory IX. ${ }^{31}$ The wall beautifully illustrates the importance of the Romano-canonical sources, as nor legislation, nor customary law is represented here.

But legal iconography can do more than just illustrate. A remarkable example of 'performing iconography' is a Ghent painting from around 1700 commissioned by a local bench of merchants: The Punishment of the Perjurer. ${ }^{32}$ The image was actually used in court, and was more exactly posted in front

${ }^{30}$ GOODRICH 2013, 498-499, reports on an experiment with two groups of court audiences; while the same arguments are used in two completely different settings, the decision taken by a court in full 'decorum' is accepted more easily than the one decided by a sober administrative body.

${ }^{31}$ LACERDA 2010a, 15-16.

32 Gillis Le Plat (1656-1724), De bestraffing van de meinedige, 1675-1724, oil on canvas, 158x280 $\mathrm{cm}$, Ghent, STA'M Museum (image available on www.erfgoedinzicht.be). A similar painting was made by Nicolas de Liemaeckere (1601-1646) in 1642 for the town hall of Assenede in Flanders, where the local accountant describes the commission as 'pour server d'avertissement et d'exemple aux gens ignorants ou méchants qui auraient la témérité de faire un faux serment, DE BUSSCHER 1866, 149-150. 
of any one having to take an oath. The image helped to keep the ritual of the oath taking continue. ${ }^{33}$ In order to 'convince' this person to be honest, the painting shows, or actually 'warns' for, what happens to perjurers. In some sense, this work of art in the forum externum is directed towards the forum internum of the viewer. ${ }^{34}$ We see a man kneeling down and raising the three oath finger of his right hand. However, as the man is lying, all members of the court (in their black gowns) and the court registrar and clerks react completely surprised. Their consternation is caused by the entrance of a devilish figure, who seizes the perjurer and leads him away from court... to the right hand corner of the painting. This is not surprising: it is the left hand, sinister or bad side of the judges (infra). This is what happens with perjurers: they end up in hell. As Lucifer in person comes and arrests the man, the courtroom stinks: a court clerk holds his nose for the smell of sulphur. It is clear that the painting used in this early-modern court has a practical, or let's say ritual role, and that, around 1700 the role of religion, heaven and hell is still pivotal. ${ }^{35}$. It is a nice illustration of the exemplary function of images in court, better known from the many exempla iustitiae. $^{36}$

The first and most inspiring example during the Ancien Régime, however, is the Last Judgment. It links God in heaven with earthly justice, administered

33 One of the roles of legal iconography indeed is safeguarding the memory of legal rituals, BÜHLER 2004, 171-173; GOMBRICH 1986.

34 GOODRICH 2011, 784.

35 And it would, be it less, continue to do so still after the French Revolution. A remarkable example of conservative and historical-religiously inspired nineteenth century court decoration, is the painting La punition du parjure by Pieter van der Ouderaa (1841-1915), 1888, Antwerp, (Old) Palace of Justice. Centrally positioned is a repenting perjurer, kneeling, together with a monk, in front of the Crucified Christ. Te wall painting is one of the only 'crucifixes' still in situ in a Belgian court house, as it is a piece of art, see Stefan HuYgEBAERT, "The Judge, the Artist and the (Legal) Historian: Théophile Smekens, Pieter Van der Ouderaa, Pieter Génard and the Antwerp cour d'assises", in: HuYGEBAERT 2018, 407-432.

36 MARTYN 2006; RODRÍGUEZ LÓPEZ 2003, 17-18. 
by Princes, jurists and aldermen. More than giving an example, it prominently legitimises the act of justice, as one of the central elements of power as such.

\section{LATE MEDIEVAL SPATIAL ORGANIZATION OF JUSTICE}

In the Late Middle Ages central courts, such as the Parlement de Paris and other French parlements, the Reichskammergericht in the Holy Roman Empire, or the territorial princely courts in the Netherlands, are established. They are composed by learned lawyers and are hosted in especially dedicated rooms of the Prince's palace. What actually happens, is some kind of de facto separation of powers. Rituals, colours and symbols - think of heraldry - had already been used by the medieval Princes and cities, so that princely and city courts could also benefit from this legitimizing character. But religiously inspired iconography in particular enhanced the charismatic legitimation. These new institutions, staffed by professional jurists and functionaries, start to decorate their working places. They are not the only 'nouveaux riches' to demonstrate what they can afford themselves. In the commercially boosting cities and wealthy district administrations, benches of aldermen and other governing corpses start to professionalize and specialize as well. A new social group of judicial personnel emerges.

Originating in this group's need to legitimize their judicial power, rituals and decorum have an important impact on the concrete organization of the new 'sites of justice'. After having judged in the open, first under a tree, later in the church and/or church portals and porches, ${ }^{37}$ tribunals move to inner

37 ACKermann 1993; Deimling 2004, 324-327; Weber 1997, 143-145. It is no coincidence that church doors are often painted red, as red is the colour of justice (infra). Even once the bigger cities had their own town hall, public punishments and pardons, like the so-called amende honourable often took place in the church porch, LECUPPRE-DESJARDIN 2013, 145. There is at least one customary court still having sessions in its age-old location: 
courtrooms of princely palaces and city halls. Even some kind of competition between the most important towns of a region can be witnessed, many of them commissioning law-and-justice-related artworks by the most famous artists of their time. ${ }^{38}$ It is the start of a rich iconographical tradition, lasting until the end of the Ancien Régime and even the nineteenth and twentieth centuries. ${ }^{39}$ One could state that the use of images of law, and particularly the decoration of judicial places, accompanies the professionalization, specialization and bureaucratization of justice administration, driven by multiple factors of State building, one of these being the reception of the learned law. Without losing a close link to divine legitimation (infra), justice moves away from religion: although in smaller villages, benches of aldermen continue having session in the Church porches, more professional courts have their own buildings; the use of irrational proofs becomes rare; originally mere canonical matters (e.g. testaments) move from the ecclesiastical to the secular forum; clerics/clercs in the administration offices are substituted by public functionaries etc.

It is no mere coincidence that, in this same period, also art itself professionalizes (e.g. with the establishment of artists' guilds) and specializes (house painters, illuminators, panel painters, engravers etc.), 'breaking away' from the Church as a matter of speech. While, apart from some heraldic work commissioned by the most powerful, almost all iconography in the Middle Ages is Christian, representing saints and scenes from the Bible, the fifteenth century witnesses some kind of 'secularization', with commissions by a rising social group, which could be seen as a layer of

the judges of the Tribunal de las Aguas de la Vega de V alencia responsible for irrigation disputes in the Horte de Valencia still gather at one of the portals of the city's cathedral, recognised as intangible cultural heritage of humanity, https://tribunaldelasaguas.org.

38 MARTYN 2006, 339. For a recent study on a great German example (Lüneburg), see HUBRICH 2018.

${ }^{39}$ HuygebaerT et al. 2018; Pleister and SCHILd 1988, esp. 86-171; RESNIK and CuRTIS 2011. 
nouveaux riches, composed by individual merchants and guilds, but also governing bodies and individual rulers, functionaries and learned men. ${ }^{40}$ In whatever chronologically ordered museum, the first rooms are filled with mere religious iconography, originating from churches and monasteries. In the fifteenth and early sixteenth century, these central themes, at first, do not really alter, but mortal men (and only exceptionally women) appear in the margin of a composition, or on one of the panels of a polyptych. ${ }^{41}$ They are often portrayed as priant. Identified sitters are statesmen, noblemen and merchants, but very often also aldermen or justice officers. When anonymous, their black (lawyers) or red (magistrates) gown points at their legal activities. Besides these individual commissions, the tradition to decorate town halls and justice rooms is an important type of work, slowly growing away from purely religious themes. The Last Judgment is the first and most important justice representation for courtrooms, but after a second wave of biblical judgments, like those of Solomon and Daniel, it becomes fashionable to have justice images inspired by mythology, history or legend. ${ }^{42}$

More generally, when the new courts install themselves in buildings, the original setting (and legitimation) of the open air justice administration continues to influence the courtroom's organization. Some see the single tree of justice repeated in the pillars of temples of justice, ${ }^{43}$ but in my opinion this is an exaggerated comparison, as one single pillar would suffice. There are, however, other comparisons to be made. Just like it was the case

40 Art historian Hans Belting (1994) famously went as far as to proclaim the art historical era before the Renaissance as 'before the era of arts', exactly because, before the Renaissance, (purely religious) art works were not seen as aesthetic objects, but as ritualistic objects of veneration.

41 A world famous example is the rich local alderman Joos Vijd on the Ghent Altar Piece, see recently PRAET and MARTENS 2019, 50-115.

42 DE RIDDER 1989; LEDERLE 1937; MARTYN 2006; SCHILD 1995, 176-192; SUTTER 2008, 29-93; VAN DER VELDEN 1995.

43 GARAPON 1997, 41-42. 
with the Hegung outside, ${ }^{44}$ in most courtrooms a space is delimited for the public on the one hand, and the so-called 'parc', where only judicial functionaries enter (the enclosure made of wood, is at the origin of the French word 'parquet as a name for the Public Ministry). ${ }^{45}$ Coloured representations of Ancien Régime courtrooms show how the judge's table or 'buffet' is mostly covered with a green cloth, whereas one, at first sight, might expect a red one, red being the colour of justice (infra). Green, however, refers to the former open air sessions of the court. Often, also the walls are painted green or covered with green curtains. ${ }^{46}$ A beautiful preserved example of an Ancien Régime courtroom, is the one of the Liberty of Bruges, ${ }^{47}$ 'portrayed' by painter Gillis van Tilborgh in $1659 .{ }^{48}$ One can see that the walls are covered with tapestries with verdant design.

Another reference to the age-old setting under the justice tree, is the adorned form of many benches, where judges, and especially the president of the court or the representative of the Prince, is seated. ${ }^{49}$ Just like some royal thrones, the seat of the judge is adorned with a baldachin. This type of canopy is a reminiscence of the former tree crown, and, de facto, many of them have leaves or branch designs. ${ }^{50}$

${ }^{44}$ JACOB 1994, 94; NETTEL 2005, 530-531.

45 JACOB and MARCHAL-JACOB 1992, 27-28 and 40-41. Dubois and DE BurCHGRAeVE 2018, 392-393, describe how the 'divine' character continues to be present in the organisation of courtrooms in the nineteenth century.

46 E.g. MARTYN and PAUMEN 2018, 219.

47 VAN AUDENAEREN 2016, 121.

48 Gillis van 'Tilborgh, Court Session in the Magistrates' Chamber of the Brugse V rije, 1659, oil on canvas, $235 \times 170 \mathrm{~cm}$, Bruges, Museum Brugse Vrije.

49 See, for instance, engravings used as frontispieces for law books (Hugo Grotius, Johannes a Sande, Gerard Wassenaer) in BECKER-MOELANDS 1989; BROOD 2012; WIDENER and WEINER 2017, 96-111.

${ }^{50}$ SUTTER 2008, 14, explains how Charles the Great in 809 issued the rule that public justice should be rendered under a roof, so that the place of justice could be used summer and winter,... an objective that took almost a thousand years to be realised, Sutter writes. However, in many regions, covered open spaces, 'Gerichtslauben', were constructed in the 
It comes, for the same reason, to no surprise that in many cases, the rod of justice, as symbol of justice, has the shape of a branch, with knots and cuts, just as if it recently has been taken from a tree (of justice). ${ }^{51}$ When centuries ago a decision was taken 'under the tree', and it had to be executed, taking with him a branch - literally as pars pro toto for the whole justice tree - was a perfect symbol for the single judge, judicial officer or executioner to legitimise his power to execute the decision taken. Throughout the centuries the shepherd's crook, the bishop's staff, the military rod, the King's sceptre, the rod of justice, and other similar symbols, like the Roman praetor's hasta, ${ }^{52}$ have been mixed up, and had locally diverging histories, but there surely is a link between the tree and the rod.

Benches, baldachins, parks and buffets help to - to use a Weberian category $^{53}$ - traditionally legitimize the 'interiorization' of the former outdoor justice administration. The decoration of the judges' rooms (both audience and deliberation rooms) with paintings, tapestries and statues further enhances this legitimation, especially given the fact that the earliest and most popular image, ${ }^{54}$ a representation of the Last Judgment, had

heart of the village, often as an annex to the town hall. Many of these roofs were decorated in the form of a 'roof of leaves'.

${ }^{51}$ BuRnELL 1948, 160-161; FISCHER 1982, 7-8, 13 and 19. See, e.g. the seated 'index' on the engraving in Joos de Damhouder's Pupillorum patrocinium (Antwerp 1564), reprinted in WIDENER and WEINER, 96; MOELANDS 2003, 167.

${ }^{52}$ LUBBERS 2019, 124.

53 WEBER 1991, 78.

${ }^{54}$ According to Jacob 1994, 48, the last Judgment is more typical for the Holy Roman Empire, while the Crucified Christ would be the most important image of Justice in France. There are surely tendencies of preferring one representation over the other, but, in my opinion, the scission is not so clearly drawn. There are many Last Judgment representations, judicially used, in the South of Europe, while the image of the Crucified Christ is attested in several Northern and Eastern regions. In the Southern Low Countries, both the Last Judgment and the Cross are normally present in courtrooms. Just like the Last Judgment (be it less anecdotally), the Crucified has an exemplary role. JACOB 1994, 56, cites Matthew 7:2: 'For with what judgment ye judge, ye shall be judged', and stresses 
already been used in church and church porch sessions of courts and benches. Most of all, however, this representation gave also charismatic legitimation to the judges. Likewise, it was the first en foremost 'example of justice', incentivizing the start of a new and long tradition of putting exempla iustitiae in courtrooms. ${ }^{55}$

\section{THE LAST JUDGMENT}

As God - following Christian tradition - is the source of life and love, the origin of all heavenly and earthly power, ${ }^{56}$ he is also the supreme and ultimate judge. God is justice. So, if secular judges take decisions, they actually fulfil a divine task. ${ }^{57}$ In Romans 2:1-4, it is written: '(1) Therefore thou art inexcusable, $\mathrm{O}$ man, whosoever thou art that judgest: for wherein thou judgest another, thou condemnest thyself; for thou that judgest doest the same things. (2) But we are sure that the judgment of God is according to truth against them which commit such things. (3) And thinkest thou this, O man, that judgest them which do such things, and doest the same, that thou shalt escape the judgment of God? (4) Or despisest thou the riches of his goodness and forbearance and longsuffering; not knowing that the goodness of God leadeth thee to repentance?' The message that justice administration is a God-given task is iconographically expressed in a most explicit way, in courtroom decoration representing the Last Judgment. It was throughout Europe, from the Middle Ages to the end of the Ancien

that the condemnation of the Christ was the 'first', i.e. most important, 'judicial error' in history.

55 De RidDer 1989; MARTYN 2006; RESNIK and CuRTIS 2011, 38-61.

${ }^{56}$ JACOB 1994, 24-33; RENOUX-ZAGAME 2015, 383-384.

${ }^{57}$ RenouX-Zagame 2015, 380-381. 
Régime the most popular image of justice. Moreover, one could state that, as law or justice is as God, it can only be seen through images. ${ }^{58}$

There is a vast amount of art-historical scholarship on the iconography, the composition, the inspirational sources, the use of colours and symbols, the local variants and the historical evolutions in the representation of the Last Day, when all souls will be judged and the good will be allowed to enter heaven, while the bad will be directed towards purgatory and hell. Both art and legal historians have also concentrated on the judicial 'use' of Last Judgment representations. ${ }^{59}$ For centuries already, the Last Judgment had been featured on Church portals, before it took up a mere judicial function outside Church, when it appeared within the emerging State's infrastructure. Said differently: before the representation of the Last Judgment went to court, the court(s) had been going to the representation of the Last Judgment. The scene, in fact, was a popular decoration of church portals, and more specifically the western one. Not on the heavenly eastern side of the ecclesiastical building, where the sun reveals its divine power every morning, but on the 'secular' western side, directed towards the community of man, was the place where man usually entered the house of God. When doing so, he had to think well of his earthly behaviour. A Last Judgment scene above the door warned him to repent and behave well, often explicitly showing the tortures of hell and the joyful reception in heaven. In Christianized Europe, many tribunals sat in judgment, exactly at this very spot. This means that, from the very beginning, the Last Judgment was a common decoration for justice places. It had to inspire the judges, who could mirror their wisdom and power in the divine example. ${ }^{60}$

58 GOODRICH 2011, 790: 'God - and truth and law - cannot be seen but only manifested in his emanations and delegation. [...] Images give law its power and glory, its aura and effect.'

59 E.g. Edgerton 1980; GrÖteCKE 1997; HARbISOn 1976; RESNIK and CurTis 2011, 33-37; SCHMOECKEL 2008; TRÖSCHER 1939; VAN LEEUWEN 1998; WACKE 2007.

${ }^{60}$ Deimling 2004, 324-327. 
Being the most important 'image' of a judgment, both in the mere religious context of the church, as in the secular use of the same site for secular judicial purposes, the Last Judgment played a great role in the 'creation' or 'passing' of legal symbols. Mainly based on John's Revelation, in a late medieval Last Judgment representation, the resurrected Christ is sitting on a rainbow. ${ }^{61}$ The Son of God is the central figure. ${ }^{62} \mathrm{He}$ is flanked by his Mother on his right hand side and John the Baptist on his left. This is the classical 'deisis', also called 'small deisis', in opposition to the 'great deisis', in which also other saints and martyrs are present. If the representation was made for judicial objectives, some saints appear to be very popular: Moses, with the Tables of the Law, but also patron saints of the jurists, like Saint Lawrence (with his gridiron) originally, but most of all, after his fast canonization in the fourteenth century, Saint Yves, with his book and/or enrolled judicial document. ${ }^{63}$

Traditionally, next to Christ's head, a lily (symbol of mercy) is seen on Mary's side, a sword (symbol of severe and powerful justice) on John's. The lily, better known as symbol of purity and chastity in Annunciations, will not survive the secularization of judicial symbolism, but the sword will. The sword was already a symbol of power in Ancient Mesopotamia, it is mentioned throughout the Bible, was pivotal in the Two Swords Doctrine, and it is, let us not forget, an instrument of capital execution in the Late Middle Ages and Early Modern Era. ${ }^{64}$ Sword and balance are still today attributes of Lady Justice. The sword merely functions symbolically today and completely lost its practical use in the Western legal tradition. ${ }^{65}$

\section{SCHWARZ 1981.}

62 And as such continuing his role as axis mundi he already had in the iconography of medieval manuscripts, JACOB 1994, 34.

63 BALdus 2004; CASSARD 2004; MARTYN 2010; SCHEMPF 2014.

${ }^{64}$ FISCHER 1982.

${ }^{65}$ CHRISTENSEN 2001. 
Also for today's symbolic balance, the late medieval Last Judgment representation plays an important role in the historical transmission of significance. 'Balancing' values and interests, as metaphor for weighing the rights and duties of parties in a dispute settlement has a millennial history. Manifold are the Bible quotes using the words 'balance', 'scales' or 'weighing'. ${ }^{66}$ In Roman times the balance stands for aequitas. ${ }^{67}$ As attribute of Lady Justice, the allegory representing one of the cardinal virtues, in combination with the sword, it does not appear before the middle of the thirteenth century. ${ }^{68}$ Already before, however, the scales are used by Saint Michael, one of the protagonists of medieval Last Day representations. The image of the Archangel Michael, mentioned in the Old Testament, is a 'construction' of the Early Middle Ages, and is partially inspired the Egyptian goddess Ma'at, who weighed the souls of the death. ${ }^{69}$

The popularity of the representation of the Last Judgment - it adorned courtrooms and churches, but was also seen on frontispieces of theological and legal books, and it was present in the city ${ }^{70}-$ made it a perfect vehicle

${ }^{66}$ E.g. Job 31:6: 'Let me be weighed in an even balance that God may know mine integrity'; Proverbs 11:1: 'A false balance is abomination to the Lord: but a just weight is his delight'; Ezekiel 45:10: 'Ye shall have just balances, and a just ephah, and a just bath'; Daniel 5:27: 'Tekel; Thou art weighed in the balances, and art found wanting'. And of course, one of the horsemen of the Apocalyps holds a balance, Revelation 6:5: 'And when he had opened the third seal, I heard the third beast say, Come and see. And I beheld, and lo a black horse; and he that sat on him had a pair of balances in his hand'.

${ }^{67}$ OSTWALDT 2009, 31-70; see also HARJu 2000, 32, ill. 7; JACOB 1994, 220.

${ }^{68}$ HARJU 2000, 51-64 en 284-285.

${ }^{69}$ JACOB 1994, 221; LACERDA 2010B, 54; LACERDA 2012, 36; RESNIK and CURTIS 2011, 18 25; RODRÍGUEZ LÓPEZ 2003, 4-6.

${ }^{70}$ E.g. in Prague, the Last Judgment is a gilded mosaic on the open square side of the cathedral; in Talinn it is posted on the outer wall of the town hall; in Monsaraz (Portugal) it is seen on top of the fresco with the good and the bad judge; the Last Judgment is represented on 'confession tables', in books of prayer, on cemetery walls; it accompanies the beatitudes, the seven virtues and the seven deadly sins etc. See, amongst many others, KORPIOLA 2018, 93-100; RODRÍGUEZ LÓPEZ 2003, 18-19. 
for the transmission of symbols like sword and balance, but it had, in my opinion, a still stronger influence for the whole concept of what a court session is, the places of the protagonists, and the use of gowns and colours. Said with some exaggeration, every Romano-canonical court session is a mirror of the Last Judgment. Centrally seated, on some kind of elevation, is the presiding judge (in case of a collegial institution the group of judges). The fact that a judge is sitting down, in order to quietly come to a good resolution, is stressed by early-modern legal authors. ${ }^{71}$ That the high judges of Princely courts are wearing a red toga is inspired by the divine example. ${ }^{72}$ Red is the colour of blood. It is the blood mentioned in Revelation 19:1113: '(11) And I saw heaven opened, and behold a white horse; and he that sat upon him was called Faithful and True, and in righteousness he doth judge and make war. [...] (13) And he was clothed with a vesture dipped in blood: and his name is called The Word of God.' On all representations of the Last Judgment, Christ is wearing a red cloth. Red gowns become common for (higher) magistrates, and more in general red is considered to be the colour of law and justice. It is, for instance, the colour of ornaments and decorations of law faculties throughout the world today.

On the right hand side of Christ, sits Mary. She mostly holds her hands up in prayer, as she is praying for the soul of man. What she is actually doing, is pleading for all repenting sinners in the world. Mary is our lawyer, our barrister and solicitor, she is advocata mundi or advocate populi. No wonder, today, the Public Ministry in continental Europe still sits on the right hand side of the judge. The Public Ministry, with titles such as avocat-général, is actually the one who has to defend the human community. The right hand side of the judge - in courts Christian the single presiding judge is the officialis as substitute of the bishop - is where the promotor sits in ecclesiastical courts. On the left hand side of the judge sits the registrar or court clerk. It is a lower functionary of the court, preparing and witnessing the judicial

${ }^{71}$ SCHOTT 2006, 55.

72 FELZ 2001. 
process, just like John the Baptist paved the way for Christ and witnessed his earthly life. The left hand side, in general, is of lesser importance. In representations of the Last Judgment, the good souls, saved for eternal life, are welcomed in heaven in the upper left side of the painting (the right hand side for the judging Christ), while the condemned go to hell in the lower right corner (to the left of the celestial Judge). Analogically, the good, repenting, thief was crucified at the right hand side of Christ, and was promised to be welcomed in heaven (Luke 23:39-42), while the bad thief died at Jesus' left hand side. Right and left stand for good and bad in religion, politics, court and culture. ${ }^{73}$

Looking at a painting like The Fountain of Life, based on Revelation 22 and attributed to Van Eyck and his office, ${ }^{74}$ through the spectacles of legal iconography, applying what has been said on the influence of the Last Judgment on the Romano-canonical procedure, the composition tells us a clear story, using judicial language. What we see, is a judge, wearing a red toga, sitting on an elevated throne. The several layers of the foreground, can be interpreted as the levels of a tribuna, on the steps of which angels are playing music. It is clear that this indeed is a tribunal, presided by God (the father in this case, not the son like in the Last Judgment, as the Son is symbolised by the Lamb, and the water completes the central Trinity representation as the Holy Spirit). At the judge's right hand side sits the advocata mundi, while John is taking the role as the court registrar. Not wearing a red mantle, nor his traditional hairy cloak, this is clearly not John the Baptist, but a much more convenient John for the court situation: John the Evangelist. He is probably not writing the Gospel (the book of Revelation), but taking notes of the divine decisions. ${ }^{75}$ If we, finally, see the

${ }^{73}$ HALL 2008, based a.o. on Matthew 25:33.

74 1441-1443, oil on panel, 181x119 cm, Madrid, Museo Nacional del Prado.

75 The Van Eyck brothers painted both John the Baptist and John the Evangelist for the Ghent Altar Piece. Both are represented as alabaster or marble statues on the outer panels of the closed polyptych. The Baptist holds the Lamb, and has a beard. The Evangelist holds 
two groups of men at the bottom, on either side of the 'fountain of life' as two opposing, litigating parties, than it is very clear who is right, and who is wrong. The Christian community with the pope, a bishop, an abbot, a cardinal, but also the emperor, a king, and a duke, is standing on the right hand side of the divine judge. This is the side of the winners. Condemned be the opposing side, the side of the Jews, whose High Priest is blindfolded and does not see the true light. While the message is religious, the artistic expression of it is clearly legal or judicial.

The red colour of justice, the places of judges, judicial functionaries and parties, the meaning of left and right, all these elements are based on religious texts, but artistically divulgated in large numbers. Looking at the images must have inspired many. Judges in the first place were to be inspired by them. This is manifest in the cases of 'dual justice', combining the Last Judgment with a secular court scene. ${ }^{76}$ In some Last Judgment paintings, the twelve apostles are present. ${ }^{77}$ Twelve, of course, had been a symbolic number since centuries (e.g. the twelve tribes of Israel), but seeing the Last Judgment as a court scene, in the presence of twelve privileged witnesses or co-deciders, it comes to no surprise that the same number was chosen when it was decided to install jury trials.

\section{LEGITIMATION AND EXAMPLE}

the poison chalice of his martyrdom, but has no beard. This confirms the hypothesis that the beardless court registrar of the Prado panel is not the Baptist, but John the Evangelist. On the inner central panels of the Ghent Alter Piece, God is flanked by Mary and the (bearded) Baptist (with book and hairy cloak).

${ }^{76}$ MARTYN and PAUMEN 2018. A Wurzburg panel (ca. 1400) with dual justice is described by JACOB 1994, 61 and plate VII.

77 E.g. the fifteenth century panel probably made for the Council of Flanders: Lieven van den Clite (1375-1422), The Last Judgment, 1413, oil on panel, 231,5x186 cm, Brussels, Royal Museum of Fine Arts, DeRidder 1989, 19-34. 
The actual judgment scene was very often also accompanied by other images, like the seven deadly sins. These representations, also, and even more directly, had a very exemplary function. Both judges and the audience, visiting the courtroom, witnessed good and bad examples. The exemplary function would be more thoroughly developed in the so-called exempla iustitiae, that were added to the Final Judgment representations as traditional courtroom decorations: stories about Solomon, Daniel, Cambyses, Zaleucus, Trajan, Herkinbald and others learned judges not to be corrupt, vain, lusty for power, partial, too lenient or not careful enough. ${ }^{78}$

Whereas most other exempla iustitiae, in the first place, wanted to remind the judges of their task, the Last Judgment not only inspired as the divine ultimate good decision, but it most of all also legitimized the judges' power, a power over life and death. A great panel exemplifying this legitimizing role is Jan Provoost's (1465-1529) rendition of the Last Day, painted for the magistrates' chamber of the Bruges city hall. ${ }^{79}$ It has some original aspects compared to the traditional Last Judgment scenes, like expressing clemency, mercy and humanity, not by the symbol of the lily but by establishing a sacra conversatio between Christ's breast stab wound and Mary's nude right breast, that had nursed the Son of God. With his left hand, Jesus is brandishing the Sword of Justice.

Special attention, however, should be drawn to the frame of this heavenly justice painting. The city magistrate first commissioned the wooden panel and frame to be made by a local carpenter, and then asked Provoost to paint on it. For the literate judges, the frame was probably as important as the image itself, as they explicitly asked to carve some verses of the Bible in it. Underneath the panel, as some kind of legend or 'bottom line', one can easily read: 'videte quid faciatis, no(n) eni(m) ho(mi)nis exercetis indiciu(m) sed D(omi)ni parali 2'. It is the text of 2 Chronicles 19:6: 'Take heed what ye do:

78 DE RidDER 1989; JACOB 1994; MARTYN 2006; SCHILD 1995, 176-192.

${ }^{79}$ Jan Provoost (1465-1529), The Last Judgment, 1525, oil on panel, 177,5x204,5 cm, Bruges, Groeningemuseum, DE RIDDER 1989, 70-73; SPRONK 1989. 
for ye judge not for man, but for the Lord, who is with you in the judgment.' The divine legitimation of the judicial function could not be more explicit: 'you, judges of Bruges, be careful and just when judging, as you are not exercising man's power to judge, but God's' ${ }^{80}$

As far as the divine legitimation of the judicial task is concerned, Psalm 81:18 is explicit:

(1) God standeth in the congregation of the mighty; he judgeth among the gods. (2) How long will ye judge unjustly, and accept the persons of the wicked? Selah. (3) Defend the poor and fatherless: do justice to the afflicted and needy. (4) Deliver the poor and needy: rid them out of the hand of the wicked. (5) They know not, neither will they understand; they walk on in darkness: all the foundations of the earth are out of course. (6) I have said, Ye are gods; and all of you are children of the most High. (7) But ye shall die like men, and fall like one of the princes. (8) Arise, $\mathrm{O}$ God, judge the earth: for thou shalt inherit all nations.

'Ye are Gods', or 'Dii estis' says the Biblical quote. ${ }^{81}$ Judges are called to the judicial function by God and can therefor count on the assistance of God's spirit. $^{82}$ It is the reason why a mass of the Holy Spirit is prayed at the start

${ }^{80}$ The other marginal texts read: 'exaltabuntur cornua iusti ps.74' (' the horns of the righteous shall be exalted', Psalm 75:10, left), 'de celo auditu(m) fecisti iudiciu( $(m)$ terra tremuit et quievit cu( $m$ ) exurgeret in indi(dium) Deus' ('Thou didst cause judgment to be heard from heaven; the earth feared, and was still', Psalm 76:8, on top), and 'cornua pecatoru(m)confringam ps.74' ('All the horns of the wicked also will I cut off, Psalm 75:10').

${ }^{81}$ In the gospel of John (10:34), when Jesus visits the Temple of Solomon and discusses with the Jews, he explicitly says that he and his Divine father are one, for which the Jews want to stone him for blasphemy ('because that thou, being a man, makest thyself God'). But Jesus answers: 'Is it not written in your law, I said, Ye are gods?'

82 RenOuX-Zagame 2015, 394-395. 
of the court day, later at the start of the judicial year; and it causes the need to have a chapel in or nearby the courthouse.

If God is the source of all justice, ${ }^{83}$ and although secular justice is not to be identified with divine justice, God is the example to follow. Joos de Damhouder (1507-1581), influential learned author of the sixteenth century who made a synthesis of customary law and Romano-canonical procedure, when explaining the civil procedure step by step, commences his book by a description of God as justice, and the duties and qualities of a secular judge. ${ }^{84}$ He opens Chapter II (Vande rechters, On judges) stating that a judge is not saying his own truth, but speaks for 'Justice and God' (cap. II, 1). Just like a balance, a judge gives each his share (cap. II, 2); a reference to the popular Roman saying ius summ cuique tribuere, but meanwhile referring to the image of the scales.

\section{CONCLUSION: A DOUBLE BUT SLOW EMANCIPATION}

Like Antoine Garapon masterly described: however logical, rational and scientific today's justice administration might be, it always was and continues to be in need of some ritual, in order to be accepted. Speaking in Weberian categories, law and justice, just like the power they emanate from, are always to be legitimised, not only rationally, but also traditionally and charismatically. ${ }^{85}$ Today's justice symbolism is indebted to many layers of influence: anthropological, mythological, biblical, historical... Each new paradigm on law and justice in a Hegelian way answers to the preceding

83 Also under Protestantism this assimilation of the judge with God continues. Calvin stresses even more the role of God in earthly matters. Even if, according to Calvin, there is a separation between State and Church, there is no separation between State and religion, DIAS CORRÊA 2015, 90.

${ }^{84}$ De DAMHOUder 1626, s.p. [frontmatter] (making references to Psalm and other biblical books), see also WIDENER and WEINER 2017, 44.

85 WEBER 1991. 
thesis, with a new antithesis, never arriving, however, at a completely new situation, but only to a synthesis comprising old and new elements. Today's symbolism and traditions regarding justice administration have age-old roots, some of which are purely religious or divine. Justice administration 'emancipated' from religion, moving from the justice tree, via the church porch and religiously decorated town halls, to be hosted in its own 'temples', from the seventeenth century onwards. ${ }^{86}$ Likewise, the newly-acquired central position of Lady Justice, as a classical virtue turned political ideal, ${ }^{87}$ in early-modern and contemporary legal iconography constitutes a major step on the path towards independence of justice (and its decorum) from its original religious roots. As another step on the same path, the iconography of Moses' tables of the law, Judeo-Christian in origin, was secularized by the French revolution and eventually evolved in a civic symbol of modern constitutionalism.

Modern justice administration in some sense 'emancipated' from medieval religion and canon law. Nevertheless, today's Western procedural law is still very much indebted to its Romano-canonical, and further religious, roots. The process 'in scriptis', rational methods of proof, the irrational proof of the oath, citation, or the institution of the Public Ministry taking the lead in inquisitorial procedures etc., they would all not exist if it hadn't been because of the Church's canon law and ecclesiastical courts. In medieval and early-modern courts quotes from canon law and the Holy Scriptures were used as arguments. And legal scholars linked many institutions, rules and juridical concepts to anchor texts in the Old and New Testament: the necessity of personal citation of the defendant before starting a proceeding was linked to 'Adam ubi es?' (Genesis 3:9), ${ }^{88}$ God's decision to destroy

${ }^{86}$ GARAPON 1997, 29, calls it a process of 'abstraction'.

${ }^{87}$ HuYGEBAERT 2016, 138-153; SCHILD 1995, 82-116.

88 SCHRAGE 1998, 365-367; RENOUX-ZAGAME 2015, 388. 
Sodom was only taken after he had personally verified the facts on the spot, ${ }^{89}$ the appointment of judges based on the case of Jethro, ${ }^{90}$ etc.

Continuing a century old tradition, contrary to the common law courts, the public prosecutor of the continental criminal procedure, for instance, literally still sits at the right hand side of the judge. Although just one of the two parties at the trial, the Public Ministry does not go and sit in the proper courtroom, where all other parties stand, both prosecuted and civil parties. One could wonder how long this can continue under the reign of article 6 of the European Covenant on Human Rights, stating explicitly that the judge should be independent and impartial. Is the judge 'impartial', when seated next to the public prosecutor, at the same table, both facing the public?

In contemporary Belgian courthouses, the Public Ministry continues to have its 'favourite' seat. Many other 'classical' features of the justice place, however, have faded. One cannot longer talk of 'temples' for instance. The court houses built in twenty-first century Belgium (e.g. Ghent, Kortrijk), have a huge amount of glass walls, inviting the broader public to come and have a look. Their thresholds are low, their services easily accessible. This transparency is the architectural answer to the crisis that Belgian justice underwent in the late twentieth century, when magistrates, lawyers and other judicial protagonists were criticised to have been living in an ivory tower as alienated functionaries, who were no longer aware of the important public service they were administering. Today, almost all historical symbols have disappeared. Already in the 1990's, the last crucifixes were withdrawn from the Belgian courtrooms - except for real 'works of art', on which has to be decided on an individual basis. The State claims to be neutral, the

${ }^{89}$ Renoux-Zagame 2015, 388-389.

90 RenouX-Zagame 2015, 389. The scene is beautifully represented on one of the engravings of the Thronus iustitiae, recently reprinted as DEN TONKELAAR, J.D.A. and DEN TONKELAAR, E.S.F. (eds.), Thronus iustitiae. 400 jaar inspiratie voor recbters, Deventer, 2014, see HELLIESEN 1977. 
judiciary claims to be independent. In the French 'état lä̈', crosses were banned from the temples of justice quite some time ago, a fact criticised by artists as Georges Rouault (1871-1958). ${ }^{91}$ In many countries, however, like Brazil for instance, crucifixes still hang in courtrooms, just like the presence and use of a chapel within a palace of justice are not questioned. For how long still?

The evolution of symbols and legal iconography in general evolves very slowly. On many existing court buildings, tablets continue to symbolise the force and pre-eminence of the written - secular - law... even though those tablets were given to Moses as the word of God. ${ }^{92}$ In Belgium, also the King's and Queen's portraits still hang in the courtrooms, as a consequence of a history started back in the age of Absolutism, when God's justice legitimised that of the King. But can one speak of independency from the executive today, if the King, as head and symbol of the executive, is looking over the judge's shoulder? In ushers' and lawyers' logos, the spade continues to serve as symbol, although Belgium's last decapitation (by guillotine, not by the sword) dates back to the First World War and the arm is prohibited to be carried along in public.

Symbols seem to last longer than laws.

${ }^{91}$ MOLINARI 2010, 164-166: Rouault painted many judges and court scenes, mostly 'in their terrifying red robes', and in het court scenes very often an impressive crucified Christ calls for a sense of clemency from the judge towards the accused, both simple human beings, whose soul the painter said to be concerned about, which he expresses in 'scènes de justice où, sous son pinceau enflam, accuses et juges se confondent sous le regard de Dieu', e.g. eod., ill. 127 (Les Justiciers, 1913), 132 (Jésus sera en croix jusqu'à la fin des temps, 1952-1956). With these paintings, Rouault explicitly critiqued the separation of State and Church, and the withdrawal of the crucifixes from the courtrooms, 'rendant plus flagrant encore l'éloignement de la justice du regard miséricordieux de Dieu', eod., 166. Other famous artistic examples witnessing the presence of crucifixes in courtrooms are Honoré Daumier's (1808-1879) Le Pardon and James Ensor's (1860-1949) Les Bons Juges.

${ }^{2}$ In France, in 1792, the Legislative Assembly decreed that its insignia would take the form of the tablets, NETTEL 2005, 534. 


\section{REFERENCES}

ACKermanN, M.R., "Mittelalterliche Kirchen als Gerichtsorte", Zeitschrift der Savigny-Stiftung für Recbtsgeschichte. Germanistische Abteilung, 1993, 530-545.

ArLinghaus, F.-J., "Mittelalterliche Rituale in systemtheoretischer Perspektive. Übergangsrite als basale Kommunikationsform in einer stratifikatorisch-segmentären Gesellschaft", in: F. BECKER (ed.), Geschichte und Systemtheorie. Exemplarische Fallstudien, Frankfurt, 2004, 108-156.

BALDus, Manfred, "Die Verehrung des hl. Ivo Hélory in den Rheinlanden, insbesondere an der alten Universität Köln", Zeitschrift der Savigny-Stiftung für Rechtsgeschichte, Kanonistische Abteilung, 2004, 269-285.

BARTLETT, Robert, Trial by Fire and Water. The Medieval Judicial Ordeal, Oxford, 1986.

BeCKer-Moelands, Margariet A., "Die Passepartout-Titelbilder der juristischen Dissertationen im 18. Jahrhundert in den Niederlanden", Forschungen zur Rechtsarchäologie und Recbtlichen Volkskunde, 1989, 75-103.

BeLting, Hans, Likeness and Presence: A History of the Image before the Era of Arts, Chicago, 1994.

Brood, Paul, "Een kijkje in de rechtszaal”, Pro Memorie, 2012, 202-205. 


\section{Georges Martynl Divine Legitimation of Judicial Powerl ISSN 2675-1038}

BÜHLER, Theodor, "Der Beitrag des Bildes zur Überlieferung von Rechtsgewohnheiten", Forschungen zur Rechtsarchäologie und Rechtlichen Volkskunde, 2004, 171-202.

BURNELL, F.S., "Staves and sceptres”, Folklore, 1948, 157-164.

CALLEWAERT, Dirk, "Wat is er aan de hand? Hand, vingers en vuist in taal en omgang, recht, religie en magie", Volkskunde, 2009.2, 95-116.

CARLEN, Louis, "Rechtsikonographisches in Kirchen Roms", Forschungen zur Rechtsarchäologie und Rechtlichen Volkskunde, 2004, 203-225.

CASSARD, Jean-Christophe and Provost, Georges (eds.), Saint Yves et les Bretons : Culte, images, mémoire (1303-2003), Rennes, 2004.

CHASSAN, M., Essai sur la symbolique du droit, précédé d'une introduction sur la poésie du droit primitif, Paris, 1847.

Christensen, Tommy P., "Carnifex et Justitia - Der Scharfrichter und sein Schwert”, Forschungen zur Rechtsarchäologie und Rechtlichen Volkskunde, 2001, 111-126.

DE Busscher, Edmond, Recherches sur les peintres et sculpteurs à Gand, aux XVIe, XVIIe et XVIIIe siècles. XV Te siècle, Ghent, 1866. 
DE DAMHOUDER, Joos, Practycke in civile saecken, seer nut, profijtelijck ende nodigh allen Schouten, Borghemeesteren Magistraten ende Rechteren, The Hague, 1626.

DEIMLING, Barbara, "De rechtshistorische betekenis van het middeleeuwse kerkportaal", in: Rolf TOMAN (ed.), Romaanse kunst. Architectuur, Beeldhouwkunst, Schilderkunst, Potsdam, 2004, 324-327.

DE RIDDER, J., Gerechtigheidstaferelen voor schepenhuizen in de Zuidelijke Nederlanden in de $14^{\text {de }}, 15^{\text {de }}$ en $16^{\text {de }}$ eeun, Brussels, 1989.

DEuTSCH, Andreas, " "Das Römisch kaisertumb allain von Gott herkompt". Zur Darstellung irdischer und himmlischer Macht im Laienspiegel von 1509”, Signa Iuris, 2012, 123-156.

Dias CorrêA, Caetano, A Reflexão Teológico-Política de João Calvino: Institucionalização do Sagrado e Direito na Aurora da Modernidade, Florianópolis, 2015.

DiLCHER, Gerhard, "Eid", in: Adalbert ERLER et al. (eds.), Handwörterbuch zur Deutschen Rechtsgeschichte, vol. 1, Berlin, 1971, 861-870.

Dubois, Gaëlle and De Burchgraeve, Amandine, "Experiencing Justice in the Cour d'assises of Brabant (1893-1913): A Place of Education and Entertainment", in: Stefan HuYGEBAERT et al. (eds.), The Art of Law. Artistic Representations and Iconography of Law and Justice in Context, from the Middle Ages to the First World War, Cham, 2018, 385-405. 


\section{Georges Martynl DivineLegitimation of Judicial Powerl ISSN 2675-1038}

Edgerton, Samuel Y. jr., “Icons of Justice”, Past \& Present, 1980, 23-38.

ERLER, Adalbert, "Gerechtigkeitsbilder", in: Adalbert ERLER et al. (eds.), Handwörterbuch zur Deutschen rechtsgeschichte, vol. I, Berlin, 1971, 1536-1539.

FELZ, Sebastian, "Die Historizität der Autorität: Des Verfassungsrichters neue Robe”, in: Viktoria DRAGANOVA et al. (eds.), Inszenierung des rechts. Law on Stage, Munich, 2011, 101-117

FISCHER, Herbert, "Stab und Schwert als gegensatzpaar der Rechtssymbolik", Forschungen zur Rechtsarchäologie und Rechtlichen Volkskunde, 1982, 3-39.

FRANCA, Marcílio, "The Blindness of Justice: An Iconographic Dialogue between Art and Law", in: Andrea PAVONi et al. (eds.), See, in Law and the Senses. Westminster Law \& Theory Lab Series, London, 2018, 159-196.

GANSHOF, François, Het 'Iudicium crucis' in het Frankische recht, Brussels, 1963.

Garapon, Antoine, Bien juger. Essai sur le rituel judiciaire, Paris, 1997.

GOODRICH, Peter, "Specters of Law: Why the History of the Legal Spectacle Has Not been Written”, UC Irvine Law Review, 2011, 773-812.

GOODRICH, Peter, "On the Futures of the Fingerpost”, Critical Inquiry, 2013, 498-531. 
GOMBRICH, Ernst H., "Ritualized Gesture and Expression in Art", in: ID., The Image and the Eye: Further Studies in the Psychology of Pictorial Representation, Oxford, 1986, 63-77.

GRÖTECKE, Iris, Das Bild des Jüngsten Gerichts. Die ikonographische Konventionen in Italien, Worms, 1997.

HALL, James, The sinister side: how left-right symbolism shaped Western art, Oxford, 2008.

Harbison, C., The Last Judgment in Sixteenth Century Northern Europe. A Study of the Relation between Art and the Reformation, New York, 1976.

HARJu, Virpi (ed.), Oikenden kuva. Bilden av rätten och rättvisan, Helsinki, Riksdagbiblioteket och Statens konstmuseum, 2000.

Helliesen, S., "Thronus Justitiae: a series of pictures of justice by Joachim Wtewael", Oud Holland, 1977, 232-266.

HuBRICH, Ann-Kathrin "Multi-layered Functions of Early Modern Courtroom Equipment: Lüneburg for Example", in: Stefan HuYGEBAERT et al. (eds.), The Art of Law. Artistic Representations and Iconography of Law and Justice in Context, from the Middle Ages to the First World War, Cham, 2018, 149164. 


\section{Georges Martynl Divine Legitimation of Judicial Powerl ISSN 2675-1038}

Huygebaert, Stefan, "Justitia, the Cardinal Virtue that became a Political Ideal", in: Stefan HuYGEBAERT et al. (eds.), The Art of Law. Three Centuries of Justice Depicted, Tielt, 2016, 138-153.

Huygebaert, Stefan et al. (eds.), The Art of Law. Artistic Representations and Iconography of Law and Justice in Context, from the Middle Ages to the First World War, Cham, 2018.

Illman MeYers, Nancy, "Painting the law", Cardozo arts and entertainment law journal, 1996, 397-406.

JACOB, Robert, Images de la justice. Essai sur l'iconographie judiciaire du Moyen Âge à l'âge classique, Paris, 1994.

JACOB, Robert and MARCHAL-JACOB, Nadine, "Jalons pour une histoire de l'architecture judiciaire", in: La justice en ses temples, Paris, 1992, 23-68.

KoCHER, Gernot, Zeichen und Symbole des Rechts. Eine historische Ikonographie, Munich, 1992.

KorPIOLA, Mia, "Medieval Iconography of Justice in a European Periphery: The Case of Sweden, ca. 1250-1550”, in: HuYGEBAERT 2018, 89-110.

LACERDA, Bruno Amaro, "As virtudes pintadas por Rafael: influência de Platão?", in: Bruno Amaro LACERDA and Mônica SETTE LOPES, Imagens da Justiça, São Paulo, 2010, 9-22. 
LACERDA, Bruno Amaro, "Personificações da Justiça", in: Bruno Amaro LACERDA and Mônica SETTE LOPES, Imagens da Justiça, São Paulo, 2010, 5463.

LACERDA, Bruno Amaro, "Balança, espada e venda: a justiça e a imparcialidade do juiz", in: Sebastião Trogo and Nuno Manuel Morgadinho dos Santos Coelho (eds.), Direito, filosofia e arte. Ensaios de fenomenologia do conflito, São Paulo, 2012, 33-50.

LeCuPPRE-Desjardin, Elodie, "The Space of Punishments: Reflections on the Expression and Perception of Judgment and Punishment in the Cities of the Low Countries in the Late Middle Ages", in: Marc BoONE and Martha Howell (eds.), The Power of Space in Late Medieval and Early Modern Europe: the Cities of Italy, Northern France and the Low Countries, Turnhout, 2013, 139-152.

LEDERLE, Ursula, Gerechtigkeitsdarstellungen in deutschen und niederländischen Rathäusern, Philippsburg, 1937.

LE GofF, Jacques (ed.), Histoire de la France religieuse. I. Des dieux de la Gaule à la papauté d'Avignon, Paris, 1988.

L'ENGLe, Susan, "Legal Iconography", in: Susan L'ENGLE and Robert GIBBS (eds.), Illuminating the Law. Legal Manuscripts in Cambridge Collections, London, 2001, 75-104.

LENZING, Anette, Gerichtslinden und Thingplätze in Deutschland, Königstein im Taunus, 2005. 
LuBBERS, Tim, "Art for the Court: A new interpretation of Gerard de Lairesse's paintings for the Court of Appeal of Holland (1688-1689)", Ond Holland, 132.2/3, 2019, 109-134.

MARTYN, Georges, "Painted Exempla Iustitiae in the Southern Netherlands", in: Reinhard SCHULzE (ed.), Symbolische Kommunikation voor Gericht in der Frühen Neuzeit, Berlin, 2006, 335-356.

MARTYN, Georges, 'Jacob Jordaens' Sint Ivo..., patroon van niet alleen de advocaten", Pro Memorie, 2010, 218-239.

MARTYN, Georges and PAUMEN, Vanessa, "Hemelse rechtspraak op Limburgse grond. Enkele rechtsiconologische opmerkingen over 'Tweevoudige gerechtigheid' (Jan van Brussel)", in: Bram VAN HOFSTRAETEN et al. (eds.), Ten definitieven recht doende... LouIs BERkevens AMICORUM. Opstellen aangeboden aan prof. dr. A.M.J.A. Berkvens, bijzonder hoogleraar rechtsgeschiedenis der Limburgse territoria (UM), ter gelegenheid van zijn emeritaat, Maastricht, 2018, 210-225.

MoElAnds, Margariet, "Die Bilder in Damhouders Patrocinium pupillorum. Eine erste Aufklärung”, Forschungen zur Rechtsarchäologie und Rechtlichen Volkskunde, 2003, 167-182.

MOLINARI, Danielle, "En écho à un «cri de miséricorde ». Victyor HugoGeorges Rouault", in: Jean CLAIR (ed.), Crime \& châtiment, Paris, 2010, 158211. 


\section{Georges Martynl DivineLegitimation of Judicial Powerl ISSN 2675-1038}

Mulcahy, Linda, Legal Architecture: Justice, Due Process and the Place of Law, London, 2011

NetTel, Ana Laura, "The Power of Image and the Image of Power: the Case of Law", Word and Image, 2005, 527-539

OESTMANN, P., "Erholung und Wandel am Ingelheimer Oberhof", in: Reinhard SCHULZE (ed.), Symbolische Kommunikation voor Gericht in der Frühen Neuzeit, Berlin, 2006, 29-55

OsTwALDT, Lars, "Was ist ein Rechtsritual?”, in: Reinhard SCHULZE (ed.), Symbolische Kommunikation voor Gericht in der Frühen Neuzeit, Berlin, 2006, 125151

Ostwaldt, Lars, Aequitas und Justitia. Ihre Ikonographie in Antike und Früher Neuzeit, in: Signa Iuris, vol. 3, Halle an der Saale, 2009.

PLEISTER, Wolfgang and SCHILD, Wolfgang (eds.), Recht und Gerechtigkeit im Spiegel der europäischen Kunst, Cologne, 1988.

Praet, Danny and Martens, Maximiliaan P.J. (eds.), The Ghent Altarpiece : Van Eyck: Art, History, Science and Religion, Veurne, 2019.

RenOuX-ZAGAme, Marie-France, "Modèles divins de la recherche du juste. Leçons des juges de l'âge humaniste", in: Jean-Philippe GENET (ed.), La légitimité implicite. Volume II. Actes des conférences organisées à Rome en 2010 et en 2011 par S AS en collaboration avec l'École française de Rome, Paris, 2015, 379-400. 
RESNIK, Judith and CuRTIS, Dennis, Representing Justice. Invention, Controversy, and Rights in City-States and Democratic Courtrooms, New Haven, 2011.

RoDríguez LóPEZ, María Isabel, "La imagen de la justicia en las artes plásticas (desde la Antigüedad hasta las postrimerías del Medioevo", Saberes. Revista de estudios jurídicos, económicos y sociales, 2003, 1-26.

SCHEMPF, Herbert, "Wer mehr Zeugen hat, behält. Rechtsikonographische Anmerkungen zu einem Rechtssprichwort", Signa Iuris. Beiträge zur Rechtsikonographie, Rechtsarchäologie und Rechtlichen Volkskeunde, XI, Halle an der Saale, 2013, 247-266

SCHEMPF, Herbert, "Zur Ikonographie des Hl. Ivo", Signa Iuris. Beiträge zur Rechtsikonographie, Rechtsarchäologie und Rechtlichen Volkskunde, 2014, 253-271.

SCHILD, Wolfgang, Bilder von Recht und Gerechtigkeit, Cologne, 1995.

SCHMIDT, C.D., "Die Hegung des Gerichts - Formen und Funktionen eines rituellen Aktes", in: Reiner SCHULZE (ed.), Symbolische Kommunikation voor Gericht in der Früben Neuqeit, Berlin, 2006, 225-249.

SCHMOECKEL, Mathias, "Procedure, proof, and evidence", in: John WITTE Jr. and Frank S. AlEXANDER (eds.), Christianity and Law. An introduction, Cambridge, 2008, 143-162. 
SCHOTT, Clausdieter, "Die Sitzhaltung des Richters", in: Reiner SCHULZE (ed.), Symbolische Kommunikation voor Gericht in der Frühen Neuzeit, Berlin, 2006, 153-186.

SCHRAGE, E.J.H., "Nedergedaald ter helle. Onderwijs in het procesrecht in de zestiende eeuw", in: B.C.M. Jacobs et al. (eds.), Een Rijk Gerecht. Opstellen aangeboden aan prof. mr. P.L. Nève, Nijmegen, 1998, 365-380.

SCHRAGE, E.J.H., Het Pad der Gerechtigheid. Bijbel, recht en picturale kunst als boekstenen van civilisatie en cultuur, Amsterdam, 2005.

SCHWARZ, R., "Die spätmittelalterliche Vorstellung vom Richtenden Christus: ein Ausdruck religiöser Mentalität", Geschichte in Wissenschaft und Unterricht, 1981, 526-553.

Spronk, Ron, "Jan Provoost", in: Maximiliaan MARTENs (ed.), Brugge en de Renaissance. Van Memling tot Pourbus, Bruges, 1998, 94-108.

SUTTER, Christiane, Flämische Gerechtigkeitsbilder des 15. Jabrbunderts: die Visualisierung spätmittelalterlicher Auffassungen von Recht und Moral, Saarbrücken, 2008.

TRÖSCHER, G., "Weltgerichtsbilder in Rathäusern und Gerichtsstätten", Wallraf-Richartz-Jahrbuch, 1939, 139-214. 
VAN AUdENAEREN, Kristel, “The Magistrate's Chamber in the Liberty of Bruges", in: Stefan HuYGEBAERT et al. (eds.), The Art of Law. Three Centuries of Justice Depicted, Tielt, 2016, 120-123.

VAN CAENEGEM, Raoul C., History of European Civil Procedure (=Civil procedure, II), in R. DAVID et al. (eds.), International Encyclopedia of Comparative Law, XVI, Tübingen, 1973.

VAN CAENEGEM, Raoul C., "Reflexions on rational an irrational modes of proof in medieval Europe", Tijdschrift voor Rechtsgeschiedenis, 1990, 263-280.

VAN DER VELDEN, Hugo, "Cambyses for example: the origins and function of an exemplum iustitiae in Netherlandish art of the fifteenth, sixteenth and seventeenth centuries", Simiolus, 1995, 5-39.

VAN ENGEN, John, "The Christian Middle Ages as an historiographical problem", The American Historical Review, 1986, 519-552.

VAN ENGEN, John, "Faith as a concept of order in medieval Christendom", in: Th. KsELman (ed.), Belief in History. Innovative Approaches to European and American Religion, London, 1991, 19-67.

VAN LEEUWEN, Jacoba, "Een tafereel van ons Heeren oordeele". De functie en de betekenis van een Laatste Oordeelvoorstelling in een middeleeuwse raadzaal', in: Maurits SMEYERS (ed.), Dirk Bouts (ca.14101475), een Vlaams primitief te Leuven, Leuven, 1998, 153-164. 
Visser, Bas and MoEns, Frank, "Gerechtsbomen”, Bomennieuns, 2006.2, 810.

WACKE, Andreas, "Rechtsprechen im Angesicht des Jüngsten Gerichts, nach Gemälden und Inschriften in Ratsstuben und Gerichtssälen", Forschungen zur Rechtsarchäologie und Rechtlichen Volkskunde, 2007, 43-56.

WebER, Max, "Politics as a Vocation", in: H.H. Gerth and C.W. Mills (eds.), From Max Weber: Essays in Sociology [Repr. ed.], London, 1991, 77-128.

WEBER, Peter Johannes, "Das Vorzeichen der Pfarrkirche St. Gallus in Kirchzarten”, Forschungen zur Rechtsarchäologie und Rechtlichen Volkskunde, 1997, 141-157.

Widener, Michael and WeIner, Mark S., Law's Picture Books. The Yale Law Library Collection, New York, 2017.

ZujIENE, Gitana, "The Headman's Sword - a Symbol Between the sacrum and the profanum", Signa Ivris, 2012, 179-186. 